\title{
POSSIBILITY OF THE USAGE OF THE VISUAL RESEARCH METHODS WITHIN THE DESIGN EDUCATION
}

\author{
Andra Irbite \\ University of Latvia \\ Aina Strode \\ Rezekne Academy of Technologies
}

\begin{abstract}
Young people are forming and will form the environment of today and tomorrow. This reinforces the necessity of the young generation's active involvement in the promotion of positive change. This approach cannot be otherwise as systemic and impossible without research and data analysis. Visual research methods, which are self-evident in design and art, are widely used in a number of other disciplines. To achieve an objective and reliable results, they often are combined with quantitative, analytic, generative and other methods. The aim of the paper - to discuss the ways of visual research methods' use in combination with systemic design thinking approach in finding new solutions in promotion of strategies for environmental and social change. Research methods-analysis of literature and case study. The results of the research show that images can be used to document the reality and can help students in the intellectual formation of concepts and strategies.
\end{abstract}

Keywords: visual research methods, images, design thinking, concepts, strategies, education.

\section{Introduction}

From time to time people tend to look back and to rethink the present definition "The New Normal" (Bratton, 2016).

At the same time, it is necessary to define what is not 'normal' or The New Abnormal. Evaluating critically, previous and current generations (we) have managed to accomplish many outstanding achievements and created just as big problems. Ida Auken (2016), the Member of Parliament of Denmark, points out all these terrible things we have happening: lifestyle diseases, climate change, the refugee crisis, environmental degradation, completely congested cities, water pollution, air pollution, social unrest and unemployment. As a result, "we lost way too many people before we realised that we could do things differently" (Auken, 2016).

It is impossible to disagree: we have a number of economic, social and environmental problems. By accepting a broader definition of the term 
'environment', encompassing natural environments, social settings, built, learning and informational environments, everyone is confronted with various situations that do not satisfy them.

Evaluation makes it necessary to construct potential future scenarios and models. This raises the questions - how can we act to change or improve human well-being and our environment - urban, social, learning, working, play or communication environment, environmental systems? Is our activity sufficient?

Different generations face distinct problems, however, young people are forming and will form the environment of today and tomorrow. This makes it necessary to actively involve the younger generation in the promotion of positive change. This approach cannot be otherwise as systemic: from definition of problems, evaluation of the situation, teamwork and communication in order to raise awareness, change attitudes and to develop strategies to promote positive solutions. Systematically, starting with smaller-scale challenges.

Depending on the scale of a problem, we are not always able to achieve the goals, however, reliable evaluation and reasonable solutions are a way how to change the attitude of our neighbours, social groups, officials of the state or local governments - to reach people, and power to make a difference. This process is impossible without research and data analysis, which means not only the identification of the problems and generation of ideas, but also the proof. Reliable data serves as a basis for the future scenarios and solutions. Here, the research methods are a very important aspect for visual assessment of the information in many cases. In turn, Design thinking in systemic discourse (Pastor, 2013, Pourdehnad, Wexler, \& Wilson, 2011), and the related methods is approach to complex environmental and social challenges.

The aim of the paper - to show the importance of systemic design thinking approach and use of visual research methods within design education in order to find new solutions in promotion of strategies of environmental and social change.

Research methods - analysis of literature and case study.

\section{Theoretical background}

Visual research methods, which are self-evident in design and art, starting from John Collier (1957) multi-disciplinary research projects, are widely used in a number of disciplines, such as sociology (Berg \& Lune, 2007; Harper, 2005, 2002), psychology (Banks \& Zeitlyn, 2015; Gold, 1986), anthropology (Collier, 1957; Collier \& Collier,1986), ethnography (Holm, 2008), education (Yurtkuran et al., 2010; Bogdan \& Biklen, 2003; Carlsson, 2001), health (Riley \& Manias, 2004; Wang \& Burris,1997) and also in a military sphere (Jenkins et al., 2016) and cross-cultural marketing research (Magnini, 2006). 
G. Holm (2008) categorizes images in two kinds: still and moving, and in three groups:

- $\quad$ subject-produced images - to record or videotape some aspects of life;

- documentary photography - they must be seen in a larger context;

- pre-existing images.

All kinds of images can be used in quantitative and qualitative research.

Visual ethnography is one of the ways of qualitative research, where photography, motion pictures, hypermedia, the web and virtual reality are gathered and analysed in order to understand and interpret the social realities and the environment.

Taking and analysing photographs is one of the most common ways to capture and explore the reality. "If I could tell the story in words, I wouldn't need to lug around a camera" (Hine, n.d.). The critical eye of camera is an essential tool in the gathering of visual information, because ,we moderns are often poor observers - the fragmentation of life makes it difficult to respond to the whole view... Leaving our specialized fields, we may by visually illiterate" (Collier \& Collier, 1967). As J. Collier and M. Collier (1967) conclude, the sensitivity and capacity of a camera makes it possible to use photography to not only show or illustrate, but also to extend the visual process and to find out more.

Depending on the purpose of the study, there is a series of methods for integration of photographs in a research and storytelling: Photo Essays (Casey \& Dollinger, 2007), Photo Elicitation (Brand \& McMurray, 2009; Lorenz \& Kolb, 2009; Clark-Ibanez, 2004; Collier, 1957), Photo-Voice (Andonian, 2010; Holm, 2008).

In the fields of Art and Design photography and the use of any kind of image can also have other objectives:

- Creation: the creation of a specific artwork.

- Visualization: image can be used as a material for further visualization of the idea or project;

- Documentation: in some cases, images can play a role of documents strictly characterizing the situation, especially in the fields of interior design, environmental, social, service and strategic design;

- Inclusion: images can be used as a material for the realization of a new design products or artworks, such as environmental design projects, web design, social posters, performances, multi-media shows.

In any of these cases described, a set of professional competences and knowledge are required, but by developing new solutions, a more extensive research is necessary in the fourth case. R. Bohnsack (2008) points out that acknowledging that pictures have the methodological status of self-referential systems also has consequences for the ways of understanding pictures as a media 
in communication. However, a communication about the pictures is to be distinguished from an understanding through pictures. To achieve an objective and reliable results, visual research methods are often supplemented or combined with quantitative, analytic, generative and other methods.

Without pretending to carry out global changes, the authors further on explore the role of pictures in multidisciplinary research and the ways of use of photography in the intellectual formation of concepts and strategies promoting the improvement of environmental change.

\section{Methodology}

The case study has been carried out in order to attract the attention to the current events in the environment, highlighting the aesthetic and functional conformity of architectonic objects with social needs.

In the present research, the case is a situation captured in the photograph and the proposed solution to a social or environmental problem.

In order to participate in the conference Design. Experience. Challenges 2016 and in the workshops, the students were given a homework in which, step by step, they had to develop specific solutions for the improvement of the environment.

The participants of the research were the students of Rezekne Academy of Technologies (RTA), Daugavpils University (DU), Daugavpils Art and Design Secondary School "Saules skola", Valmiera Secondary School of Art, who study design; 37 students in total.

The objective - to take photographs of the life / study environment, paying attention to the objects, things, processes that address in a positive or negative aspect. By the analysis of the results, to assess, to draw conclusions and to propose a solution (Table 1). Task execution time -2 weeks.

Several students worked in groups and submitted their common view on environment problems, therefore, the number of analysed cases -21 .

Table 1 The stages of strategic problem solution

\begin{tabular}{|l|l|}
\hline Stage & Activity \\
\hline 1. Define & Answer the questions: \\
& What problems do you encounter in your / other people's life, in your \\
surroundings or global environment, private or public space? & What do you want to fix, find out, understand, change or improve? \\
& $\begin{array}{l}\text { Formulate the basic problem. } \\
\text { Formulate the scale of the main problem and sub-problems. } \\
\text { Draw the overall structure of the problem - systems diagram. }\end{array}$ \\
\hline
\end{tabular}




\begin{tabular}{|l|l|}
\hline 2. Explore & $\begin{array}{l}\text { Work individually / in groups - photo sessions. Take photographs of } \\
\text { your /other people's environment, focusing on objects, things, } \\
\text { processes, systems that address you in a positive or negative aspect. }\end{array}$ \\
\hline 3. Understand & $\begin{array}{l}\text { Analyse all the collected materials (photographs). Answer all or some } \\
\text { of the questions: Who? Where? When? How? Why? } \\
\text { Write down the answers, systematise them. Do you need more photo } \\
\text { sessions? } \\
\text { Is it necessary to add other methods, such as focus group interviews, } \\
\text { field or statistical analysis to understand the whole problem? }\end{array}$ \\
\hline 4. Develop & $\begin{array}{l}\text { Answer the questions: } \\
\text { Can / cannot I /we do something to change / improve the } \\
\text { environment, human wellbeing, to solve social or global problems? } \\
\text { If I /we cannot change the reality, how can we change the attitude of } \\
\text { our neighbours, social groups, officials of the state or local } \\
\text { governments? } \\
\text { Formulate the solution of the problem. }\end{array}$ \\
\hline 5. Share & $\begin{array}{l}\text { Define the final product - will it be - an image, social poster, } \\
\text { environmental / interior project, installation, performance, } \\
\text { multimedia show, strategic design project? } \\
\text { Prepare the presentation. }\end{array}$ \\
\hline
\end{tabular}

\section{Results}

The respondents submitted photographs with commentaries on the problem and its solution. Firstly, the themes of photographs were analysed (Table 2).

In general, the focus in the photographs is on the places, which require changes. In the commentaries, several respondents mention unpleasant feelings that abandoned and demolished buildings cause, located in cities besides pedestrian ways.

While in the cases A1, A2, badly maintained urban environment highlights three currently common problems: environmental pollution, alcoholism and poverty. For the improvement of the situation, it is proposed to set the signs reminding that environmental pollution is prohibited, to pave paths, that will create an atmosphere of a public place for those who enjoy the beauty of nature, as well as to arrange recreation areas. The solution for the attraction of society's attention - an organized event of waste cleanup at a certain place. An artistic performance, during which, a person is plastered with different waste, until he cannot bear the weight (or light wood construction, that eventually breaks). A social context of positive social changes is essential-society's attitude, as, by cleaning up and maintaining the environment, it is possible to achieve society's appreciation and evaluation of the beautiful in their city, develop of piety towards the nature. 
Table 2 Themes of photographs

\begin{tabular}{|c|c|c|c|}
\hline Theme & Subtheme & $\begin{array}{l}\text { The number } \\
\text { of cases }\end{array}$ & $\begin{array}{l}\text { The codes of } \\
\text { cases }\end{array}$ \\
\hline \multirow[t]{3}{*}{$\begin{array}{l}\text { Environmental } \\
\text { orderliness }\end{array}$} & $\begin{array}{l}\text { Recreational area along the } \\
\text { river }\end{array}$ & 2 & $\mathrm{~A} 1, \mathrm{~A} 2$ \\
\hline & $\begin{array}{l}\text { Arbitrary animal cemetery } \\
\text { close to residential buildings }\end{array}$ & 1 & A3 \\
\hline & $\begin{array}{l}\text { The necessity of the } \operatorname{dogs} \\
\text { walking area }\end{array}$ & 1 & A4 \\
\hline \multirow[t]{4}{*}{ Abandoned buildings } & In city & 1 & B1 \\
\hline & In rural area & 2 & $\mathrm{~B} 2, \mathrm{~B} 3$ \\
\hline & Factories & 3 & $\mathrm{~B} 4, \mathrm{~B} 5, \mathrm{~B} 6$ \\
\hline & Public buildings for relaxation & 2 & $\mathrm{~B} 7, \mathrm{~B} 8$ \\
\hline \multirow{2}{*}{$\begin{array}{l}\text { Visual design of } \\
\text { buildings }\end{array}$} & Shop windows & 2 & $\mathrm{C} 1, \mathrm{C} 2$ \\
\hline & Graffiti & 1 & $\mathrm{C} 3$ \\
\hline \multirow{3}{*}{$\begin{array}{l}\text { Pedestrian paths, } \\
\text { crossings }\end{array}$} & Railway crossing & 1 & D1 \\
\hline & City street junction & 1 & $\mathrm{D} 2$ \\
\hline & Pedestrian road & 1 & D3 \\
\hline $\begin{array}{l}\text { Household problems of } \\
\text { the residents of multi- } \\
\text { storey buildings }\end{array}$ & Laundry drying & 1 & E1 \\
\hline \multirow[t]{2}{*}{$\begin{array}{l}\text { Accessibility of } \\
\text { environment }\end{array}$} & $\begin{array}{l}\text { Stairs of entrance into public } \\
\text { buildings }\end{array}$ & 1 & F1 \\
\hline & Stairs of tram & 1 & F2 \\
\hline
\end{tabular}

Several social photographs demonstrate urban environment situations that are uncomfortable for the users. For instance, the case D1 draws attention to the following situation: the railways under the overpass is a frequent crossing point of Rezekne pedestrians, as it is the shortest way that allows to save some time. When crossing the railways in a prohibited place, people put themselves in danger, for instance, by falling and injuring themselves. The proposal is to organize that place, create a safe pedestrian crossing with warning signs and colourful luminescent stickers that will mark the numerous rails.

In cases $\mathrm{C} 1, \mathrm{C} 2$, the objections relate to the tendency of decorations of shop windows - cover window displays with advertisements, which cover all the window areas. Visually the windows are transferred into non-transparent walls and an important design direction - the art of shop-windows decoration is developing.

The society's most painful and challenging issue is the demolition of abandoned buildings or their maintenance for new functions to be carried out. Taking into account safety considerations, the respondents proposed to use these places for non-formal art projects, organization of exhibitions. It is important to stop the demolition processes of these buildings, to fence them off, providing a 
safe environment for the visitors. A temporary solution is to cover the windowpanes with decorative panels. This way, the transitional period until the renovation of the building is ,lived through" (Figure 1).
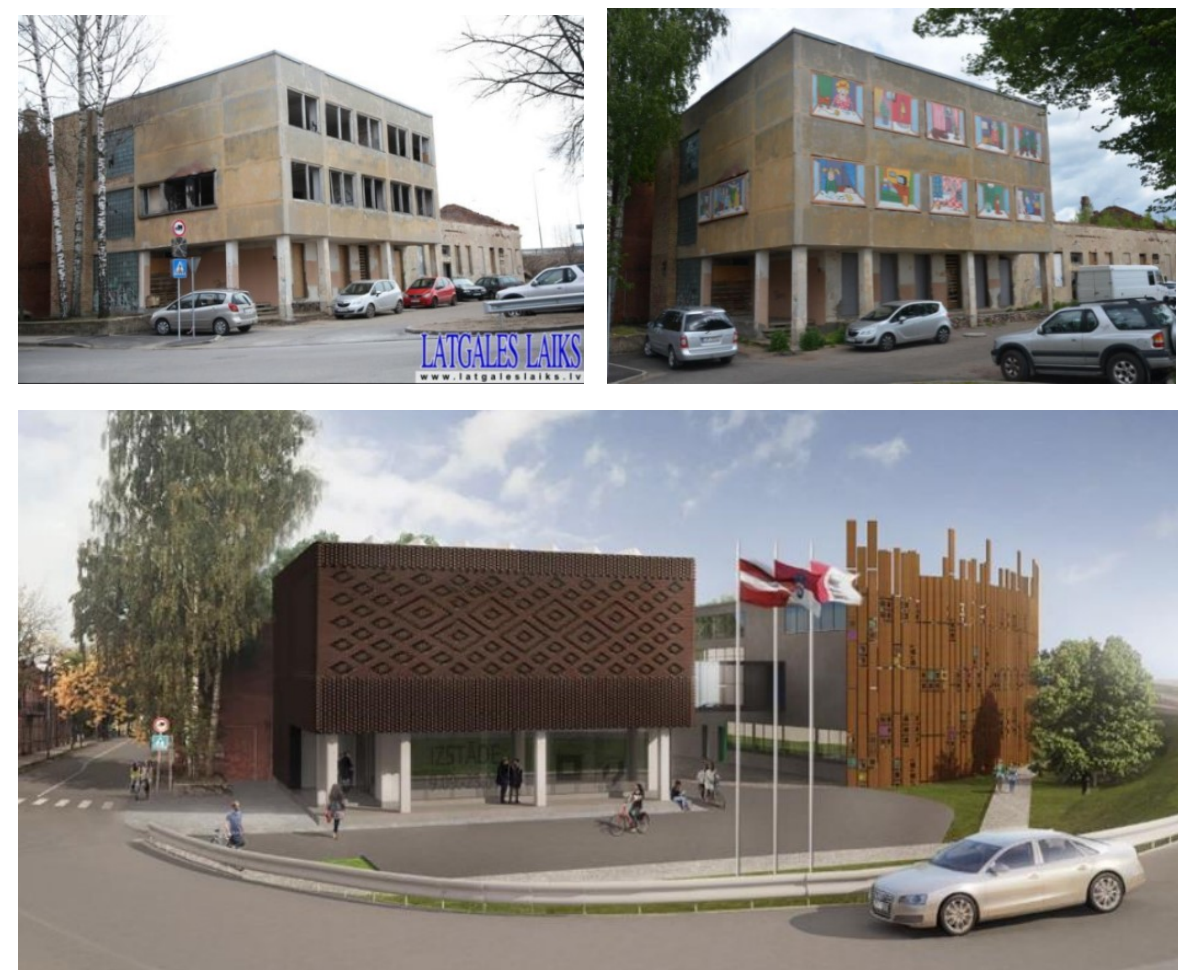

Figure 1 The current state of the building and the project of the new building of "Saules skola" (B1)

Even though it is not a new experience, the panel design solutions differ, according to the new functions of the building.

In the case D3, the respondent draws attention to the consequences of imprudent decisions (Figure 2). Just built pedestrian walkway, which has been planned just "in the trees' way" The trees after a month are cut down, in order not to cause inconvenience for the pedestrian traffic.

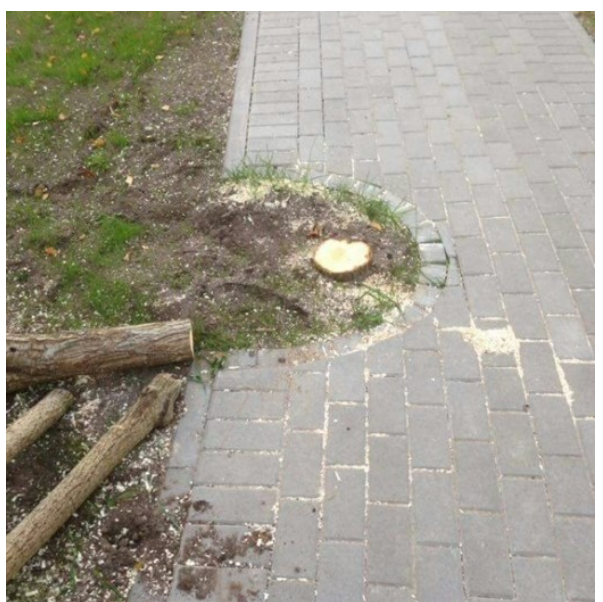

Figure 2 Unsuccessful planning of the walking way (D3) 
In the previously reviewed cases of recording urban environment facts, the suggestions of the respondents were applied for the identification of social problems, development of proposals and are more traditional. While the students of DU have carried out a complex task, undergoing all strategic design stages. The students were working in groups and in their presentations have demonstrated the process of Daugavpils image creation, beginning with a problem and definition of opportunities, idea generation, and finishing with a design product offer with an aim to improve and promote city's recognition and development of the tourism sector.

In this case, the defined key problem was the lack of the city's identity because of an insufficient reflection of the availability and uniqueness of nature, historical and cultural resources in the information sources. The students believe that currently Daugavpils is associated only with the Rothko Art Centre. In order to define the interconnected influencing factors and involved parties, that determine and affect the development of the city's image and promote the competitiveness of the tourism sector, the students have carried out the factor analysis and developed the system diagram. After the analysis of available information sources - homepages, advertisements and written press - carrying out several photo shoots and observation studies, analysing the photographs taken and the research results, the students defined the factors promoting and impeding the development of the tourism sector.

The following factors of the strategic advantage were formulated: geographical breakdown, the proximity of borders of three countries; developed infrastructure; a large concentration of educational and cultural institutions (museums, the Rothko Art centre); cultural diversity and identity; industrial, military, cultural and historical heritage (a fortress, historical buildings); natural resources (lakes and the river Daugava); science.

The students defined the inhibitory factors of local tourism development in Daugavpils:

1) Insufficiency of information on the homepages, insufficient environmental information system;

2) Unsuccessful location of the tourism information centre;

3) Lack of information connecting points;

4) Insufficiency of advertisement promotion;

5) City's image and branding.

Next, the students defined three key words that could characterize Daugavpils and the spirit of the place: Adventure, Feelings, Complexity.

By analysing the collected information and data, three groups of challenges/opportunities and tasks have been defined.

1) To offer the solutions for the improvement of information systems. 
Students developed a number of proposals, they plan to introduce responsible persons with them.

2) To develop the provision of unique services. Services as adventure.

Cultural, historical and industrial tourism:

- Hop-on hop-off 'Rothko tram' running on a line that connects the city centre with the fortress and the Rothko Art Centre. WHY? Hop-on hopoff buses are in many cities, but Hop-on hop-off tram will be only in Daugavpils. Along the way, there are many sightseeing objects.

In the development of the proposal, the photograph created during the photo session has been used. Colours - from the corporate identity of the Rothko Art Centre (Figure 3).

- Thematic tours (interactive entertainment in museums, military objects).

- Distillation courses - a service of the Schmakovka museum (schmakovka is the national drink with a long history).

- Gastronomic tourism:

As the people of various nationalities live in Daugavpils, there is the opportunity to taste the dishes of various national cuisines. As it turns out, there are three products that characterize the taste of the city in general: belash (the pie with various fillings), schmakovka and chocolate - the last mentioned product is especially loved by the inhabitants of Daugavpils. So the offer of the day: Promenade Belash, shmakovka Dinaburg, Czar pancakes with chocolate.

- Health improvement:

Schools of healthy lifestyle, slimming procedures and other.

3) To develop a vision for the city's image and slogan.

In the process of the development of the image of Daugavpils, the students defined the key words: spaciousness, water, art, colour, history, fluency, which allowed developing the slogan: Water. Colour. City (Figure 4).

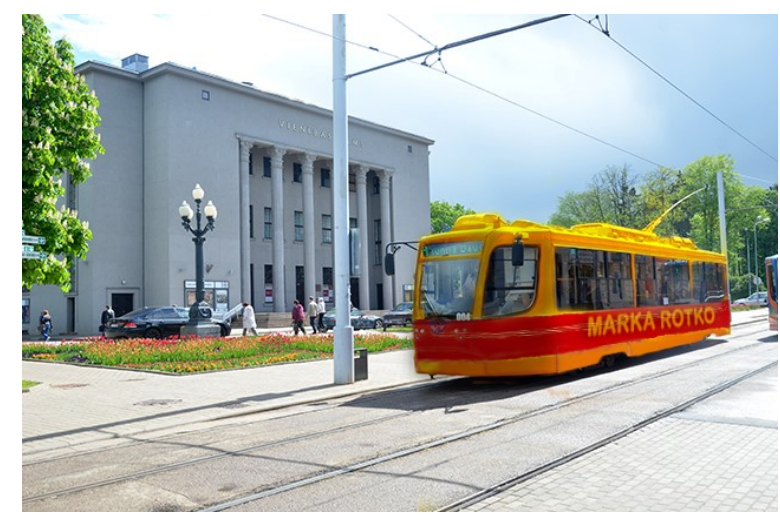

Figure 3 'Rothko tram'

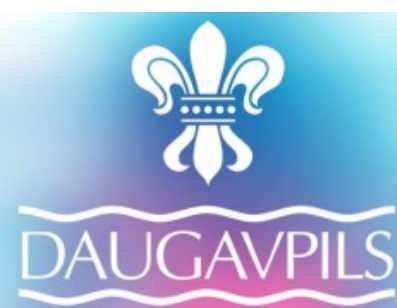

WATER.COLOR.CITY

Figure 4 Logo of Daugavpils with the slogan 
As a result, the students have developed an action strategy and prepared the presentation also including a Photo Essay and actual proposals, in order to present them to the local government representatives.

As the experience of the previous student work groups, who has carried out similar task, has shown, the responsible officials follow the proposals based on the research of the young generation, and the actual improvements are made, for instance, public transport scheme on the homepage of the local government has become clearer.

It demonstrated the efficiency of the approach and the necessity to continue the active involvement of youth in social and environmental problem solving processes. These activities will serve as a base for knowledge and experience acquisition that will be necessary in dealing with future challenges of larger scale.

\section{Conclusions}

1. Visual ethnography, as one of the ways of qualitative research, is widely used in a number of disciplines in order to understand and interpret the social realities and the environment.

2. An essential role of the visual research methods' application is the stage of pre-design, when the current situation is studied, design tasks (ethnographic research) are defined, analogues examined and analysed (case study), ideas generated (visualization).

3. The case study has shown that, in the process of design studies, it is important to develop critical and creative thinking, by applying the systemic approach in finding new solutions for the development of design projects. By consequently carrying out design strategic thinking stages, Define-ExploreUnderstand-Develop-Share, a binding design product offer has been acquired.

4. The inner experience shows that the responsible officials follow the proposals based on the research of the young generation and the actual improvements are made. It demonstrated the efficiency of the approach and the necessity to continue the active involvement of youth in social and environmental problem solving.

\section{References}

Andonian, L. (2010). Community participation of people with mental health issues within an urban environment. Occupational Therapy in Mental Health, 26, 401-417.

Auken, I. (2016). Welcome to 2030. I own nothing, have no privacy, and life has never been better. World economic Forum. Retrieved 12.12.2016. from https://www.weforum.org/ agenda/2016/11/shopping-i-can-t-really-remember-what-that-is/ 
Banks, M., \& Zeitlyn, D. (2015). Visual Methods in Social Research. Sage. ISBN 978-44626974-9

Berg, B. L., \& Lune, H. (2007). Qualitative Research Methods for the Social Sciences (8th ed.). Pearson. ISBN-13: 978-0205809387

Bohnsack, R. (2008). The Interpretation of Pictures and the Documentary Method. Forum: qualitative research, 9 (3), 26-31. Retrieved 12.12.2016. from http://www.qualitativeresearch.net/index.php/fqs/article/view/1171/2592

Bogdan, R., \& Biklen, S. K. (2003). Qualitative research for education: An Introduction to Theories and Methods (5th ed.). Pearson. ISBN-13: 978-0205482931.

Brand, G., \& McMurray, A. (2009). Reflections on photographs: Exploring first-year student's perceptions of older adults. Journal of Gerontological Nursing, 35 (11), 30-35.

Bratton, B. H. (2016). The New Normal. Retrieved 17.12.2016. from http://theissuemagazine. com/the-new-normal

Carlsson, B. (2001). Depicting experiences. Scandinavian Journal of Educational Research, 45 (2), 125-143. Retrieved 21.12.2016. from http://www.tandfonline.com/doi/abs/ $10.1080 / 00313830120052723$

Casey, P. F., \& Dollinger, S. J. (2007). College students' alcohol-related problems: An autophotographic approach. Journal of Alcohol and Drug Education, 51 (2), 8.

Clark-Ibanez, M. (2004). Framing the social world with photo-elicitation interviews. American Behavioral Scientist, 47 (12), 1507-1527.

Collier, J. Jr., \& Collier, M. (1986). Visual anthropology: Photography as a research method. Albuquerque: University of New Mexico Press. ISBN-10: 0826308996

Collier, J., \& Collier, M. (1967). Visual Anthropology: Photography as a Research Method. The university of New Mexico Press. ISBN 0-8263-0898-8.

Collier, J. J. (1957). Photography in anthropology: A report on two experiments. American Anthropologist, 59, 843-859. Retrieved 21.12.2016. from http://onlinelibrary.wiley.com/ doi/10.1525/aa.1957.59.5.02a00100/epdf

Gold, S. (1986). Ethnic boundaries and ethnic entrepreneurship: A photo- elicitation study. Visual Sociology 6 (2), 9-22.

Harper, D. (2005). What's new Visually? In N. K. Denzin \& Y. S. Lincoln (Eds.), Handbook of qualitative research (3rd ed.) (pp. 747-762). Thousand Oaks, CA: Sage. ISBN 0-76192757-3.

Harper, D. (2002). Talking about pictures: a case for photo elicitation. Visual Studies, 17 (1), 13-27. Retrieved 21.12.2016. from http://www.nyu.edu/pages/classes/bkg/methods/ harper.pdf

Hine, L. (n.d.). Lewis Hine Quotes. Retrieved 21.11.2016. from https://www.brainyquote.com/ quotes/quotes/l/lewishine161834.html

Holm, G. (2008). Visual Research methods. Where Are We and Where Are We Going? In S. N. Hesse-Biber and P. Leavy (Eds.), Handbook of Emergent Methods (pp. 345-356). The Guilford Press. ISBN 978-59385-147-7.

Jenkins, K. N., Murphy, A., \& Woodward, R. (2016). Photo-Elication in Military research. In A. J. Wiliams, K. N. Jenkins, M. F. Rech, R. Woodward (Eds.), The Routledge Companion to Military Research Methods (pp. 345-356). Routlege. ISBN 978-1-47244275-8.

Lorenz, S., \& Kolb, B. (2009). Involving the public through participatory visual research methods. Health Expectations, 12, 262-274.

Magnini, V. P. (2006). Photo-Elicitation as a Tool to Alleviate International Marketing Mistakes. Global competitiveness, 14 (2), 81. 
Pastor, E. (2013). The Other Design Thinking. Retrieved 21.12.2016. from http://www.humantific.com/the-other-design-thinking/

Pourdehnad, J., Wexler, E. R., \& Wilson, D. V. (2011). Systems and Design Thinking: A Conceptual Framework for Their Integration. Retrieved 21.12.2016. from http://repository.upenn.edu/cgi/viewcontent.cgi?article=1009\&context=od_working_pa pers

Riley, R. G., \& Manias, E. (2004). The uses of photography in clinical nursing practice and research: a literature review. Journal of Advanced Nursing, 48 (4), 397-405. DOI: 10.1111/j.1365-2648.2004.03208.x

Yurtkuran, S., Kaplan, I., \& Taneli, Y. (2010). Photography in architectural education: A tool for assessing social aspects of the built environment. Procedia - Social and Behavorial Sciences, 2 (2), 2583-2588. Retrieved 21.12.2016. from http://www.sciencedirect.com/ science/article/pii/S1877042810004179

Wang, C. (2003). Using photovoice as a participatory assessment tool: A case study with the homeless in Ann Arbor. In M. Minkler and N. Wallerstein (Eds.) Community-based participatory research for health (pp. 179-196). San Francisco: Josey Bass. 